\title{
The Writerly Reporter: Saki as Correspondent for The Outlook
}

\author{
Lorene M. Birden
}

University Technology Institute of Dijon, France

\begin{abstract}
In February of 1914 Saki began to write Potted Parliament ('potted' being the English expression for 'in a nutshell' or 'for dummies') for The Outlook, a London weekly. His commentary contains much satire. Through his tone and barbed comments, he does more than report the speeches and events. He also includes conversations, which are not usually presented in Parliamentary reports. In addition, Saki inserts fictional characters into his reports. Several examples of Saki's reports and the reasons for and results of his fictional insertions are presented here. This technique allows for the satirical tone mentioned above and allows a mix of styles, from the most reportedly to the most humorous. It makes a distinction between the reportedly voice, which is supposed to be faithful to the facts of the Parliamentary sessions, and the voice of the fictional characters, which can carry the comment and the risk of irresponsibility. These observations suggest that Saki was concerned about a certain form of protection from the censorship of the time and from the average reading public which still took political reporting seriously. Saki's choice of tones constitutes a departure from habitual political reporting which is refreshing and contributed to a release from earnestness.
\end{abstract}

Keywords: humour, journalism, Hector Hugh Munro, Saki, The Outlook.

\section{Introduction}

In February 1914, the English humourist Saki began writing for a weekly magazine called The Outlook. On the surface, this was simply a continuation of his authoring activity until then; Saki's work had always involved submitting short pieces that were published in dailies such as The Westminster Gazette and The Morning Post or weeklies such as St Paul's and The 
Bystander, which were only subsequently collected into book form [1]. What was different in this case is that Saki was hired as a reporter rather than as a fiction writer; his task was to cover the Parliament sessions.

It was not the first time that Saki worked in a reporting capacity; he had been a correspondent for The Morning Post from 1902 to 1909. It was also not the first time that he wrote about politics; his foreign correspondence was full of political analysis as well as simple reporting, and his fame had first come from his political satire, The Westminster Alice. It continued with other series, The Political Jungle-Book and Not So Stories, and with separate short pieces such as The Angel and his Lost Michael and More about Him. However, the Outlook assignment constituted the first time that Saki was hired to combine his capacity for reporting and his keen powers of political observation and do political reporting and commentary. The articles are called The Potted Parliament, which can be glossed as 'Parliament in a nutshell' or 'Parliament for Dummies'.

But one could ask whether Saki was truly giving himself over to political reporting. Certainly, he was summarizing the activities taking place in the House of Commons which concerned the policies that the government was attempting to implement: the Suffragette agitation, the Irish Question (i.e., the independence of Ireland from the United Kingdom), the Balkan turmoil, and Germany's rising aggression. However, different elements of the correspondence show that we still have the writer and humourist with us.

It is useful to describe the political situation to which this correspondence was reacting in order to elucidate the reasons for hiring the humourist Saki to write it. In 1914, England had a Liberal government, dominated by the masterful H. H. Asquith, the fiery David Lloyd George and the wily Winston Churchill, and it was very concerned with giving Home Rule to Ireland in the teeth of the Conservative opposition. This party had been in power since 1905, had maintained a majority in two back-to-back elections in 1910, and had brought about many changes in the English political and social system. It had ended the Boer War, regulated trade union activity, improved the Navy, negotiated several crippling strikes, and introduced pensions, health insurance and unemployment compensation.

It could be suggested that such an effective government was difficult to attack or criticize. But The Outlook was openly conservative, expressing all the ardour of the opposition. Through its partisan, strident tone, The Outlook can be considered the last truly politicized periodical of the time, the last to abandon the close link between the press and the parties which had become more and more illusory as the Edwardian period progressed [2]. Saki was therefore free to excoriate the party which he saw as the most irresponsible. And Saki would certainly have felt free to attack the government by his own predilections. Many events and considerations had made Saki more moderate - for example, his eye-witnessing of the Russian government's brutal suppression in the January 1905 uprising in Saint Petersburg - but he was still essentially conservative. He was still, therefore, writing as a relatively hostile witness to the Parliamentary proceedings.

However, this hostility did not lead to a hostile tone. On the contrary, Saki leavens his criticism with humour. The tone can be very biting, but it is the bite of satire rather than of vituperation. The light tone serves to turn a column of political reporting into a satire on the government. Saki presents to the reader the habitual pillorying that this periodical engages in, but with a perspective that matches his usual intentions - his 'purport', as Seamon (1987: 374), would say -: that of exposing the foibles of society through the bite of satire. He thus takes on Chesterton's (1926: xii) "coat of mail of flippancy, at once as sparkling and impenetrable as the costume of a harlequin", using his light, epigrammatic language to expose the government's failings [3]. This study illustrates the use of Saki's harlequinesque talents by presenting excerpts of Potted Parliament and highlighting the main characteristics of the 
humour perpetrated: the presence of irony, epigram, and humorous metaphor; the use of different tones; and the insertion of different types of content and personages.

\section{The corpus and its elements}

It is this question of content which first alerts the reader to the fact that Potted Parliament is not a standard political chronicle. Political reporting of the beginning of the twentieth century in England usually involved descriptions of, and perhaps quotations from, the speeches and discussions presented in the House of Commons. Saki takes a different approach right from the first report, published on the $21^{\text {st }}$ of February:

To the House, where I met Valerian, who sits for North Subbage in the Ministerial interest. His constituency is Liberal to the core, and he is liberal to the constituency, so they are probably mated for life - unless of course he should contribute over-liberally to the party funds and be suitably rewarded. It used to be a saying that all Radicals love a lord; of the lords created under the present regime it may be said that they are people who have expensively loved the Radicals. Doubtless there are many men in the House who know how to dress; Valerian is one of the comparatively few who put that knowledge into practice. (21 Feb: 232)

This last sentence contains the most surprising content. Commenting on a member's dress habits would usually be seen as superfluous and little to the point in a political column. Not only does Saki introduce such seemingly extraneous observations, but he does so in the very first paragraph of his dispatch. The unusual content continues in the second part of the paragraph:

\footnotetext{
With [Valerian] was Clode, who sits on the Conservative side of the House for some West of England constituency. The two were at the tail end of a decision when I came upon them. "I'm only a private member, and I'm in nobody's confidence," Valerian was saying, "but you may take it from me that there will be no General Election this year. The last one was in December 1910, and we're not going to hurry the next one on before it's due. Why should we?"

"If there is one democratic movement of modern days that is thoroughly dead and disowned," said Clode, "it is the Radical agitation of the 'nineties for Triennial Parliaments."

"Not dead, exactly," said Valerian; "it will revive as soon as ever your party comes in with a big majority on some evanescent issue."

"After all," admitted Clode, "in avoiding an appeal to the country your party is merely acting on the Gladstonian definition: 'Liberalism is trust in the people - modified by caution.' It's inevitable, I suppose, at times, that the caution should be more conspicuous than the trust." (21 Feb: 232)
}

This first article continues with two members in teasing conversation. Thus, rather than begin by a description of the House or a report on the major discussions of the day, Saki begins by a casual talk representing a human point of view and not a larger political point of view. It is in this indirect way, through an introduction on a secondary theme that Saki brings in his political commentary. The result is to give a more down-to-earth tone to his political correspondence.

The tone is much more out of the ordinary as it is not the sober one of Parliamentary reporting, but that of Wildean repartee. The presence of humour is of course the most original aspect of this chronicle. In this opening paragraph, the plays on words centring on the meanings of the word 'liberal' and the difference between 'dear' and 'expensive' are all humorous. The dispatch is also full of raillery; each of these Members of Parliament criticizes the other's party. It can be said that the down-to-earth tone in itself allows more humour and satire. The descriptions and reported conversation of Valerian and Clode allow Saki to begin 
his chronicle in irony and to colour the commentaries with it. He makes it clear right from the beginning that what follows is going to be as much Sakian narrative as political reporting.

Finding a conversation quoted in a passage of political correspondence is already unusual; political reporting usually quotes speeches and debates. In addition, this informal dialogue is taking place outside the Chamber. The humorous insult is frequent in Parliament; it can be used during the discussions with great effect. However, these political remarks are systematically reserved for the Chamber in order for them to have the full effect and the full public attention. Here Saki presents two minor members who show as much humorous acuity as their leaders, but are venting it in the wings and within hearing of a reporter. Everything in this dialogue makes it unusual in the context of political correspondence. Saki is operating at the boundaries of political reporting.

It cannot be said that Saki is functioning completely outside the boundaries, as he is in fact presenting a chronicle of the sessions. However, there is - besides the elements indicated above - another non-humorous aspect of the reporting which suggests that Saki is willing to dilute the chronicle. There are passages in which Saki reports events clearly, such as this one:

On Monday night [Leo Chiozza Money] could not escape from the awkwardness of having to admit that the American labour market was necessarily affected by the constant influx of immigrant workers, while our own labour market is eased by the steady drain of emigration [...] (21 Feb: 232)

Saki presents the difficulties of keeping workers in England quite clearly here. Another passage is less clear, but still communicates information to the reader:

Sir John French and Sir John Ewart at last made an "Honest John" of their co-signatory by giving him an irresistible lead into the paths of resignation. John Seely trotted out again into the wilderness, bearing the signs of the congregation upon him [...] (1 Apr: 432)

Even with the implicit metaphor of the scapegoat and the play on the expression 'Honest John', it is clear that Saki is announcing the resignation of John Seely, the War Minister, who was considered responsible for the Curragh Incident involving a botched attempt to use English troops to quiet Ulster unrest. The designation 'co-signatory' contributes to the reader's understanding, as news of the use and misuse of signed documents in the affair was public knowledge by the time Saki reported on the resignation [4].

In contrast to these excerpts, there are passages in which a reader can only be properly informed of the actual event by either being present in the House or reading other accounts of it. Here is an example:

Question-time was decorated by the appearance of the estimable Gulland in a white sheet. Tragic spectacle of the only man who had been able to make a Government candidate popular explaining that he never meant to do it. (21 Feb: 232)

Even the reader of the time would have had difficulty remembering John Gulland, Junior Lord of the Treasury. In addition, although the metaphor of the 'white sheet' would have been recognizable - it was a sign of penance, or in this case of apology - the reader would need to know which candidate Gulland had succeeded in "making popular". This oblique approach to reporting is yet another sign that Saki is committing the overall irony of making political reporting secondary in a weekly column that is intended to present political reporting.

However, this gesture is secondary to the many humorous gestures that are made to make the same point. One final gesture must yet be brought to the fore. We can, hence, return to the first passage, in which Valerian and Clode are quoted. The unusual content of their dialogue leads the researcher to wish to discover the identity of these Members of Parliament. 
However, on opening the main work of reference for the government, Dod's Parliamentary Companion (1914: 262-263), one finds no Valerian and no Clode. One finds only a certain William Clough, a Liberal member representing the West Riding (i.e. western Yorkshire). Even the town or village of North Subbage is absent from an atlas of Great Britain [5]. This shows that Messrs Valerian and Clode do not exist; Saki has inserted these fictional characters in the real environment of Parliament and descriptions of these imagined activities in a real political chronicle [6]. As a result, the Parliament itself suffers a degree of fictionalization, creating the image of an unreal Parliament, severed from reality - not just a 'potted', or briefly explained Parliament, but a 'potty', or addled, confused one as well. Clode functions as a sort of Greek chorus, bringing out the fantastic side that Saki wants to highlight in the government.

This situation is the reverse of that of Saki's short stories Ministers of Grace or Canossa; there he inserts a real politician in a fictional environment. Here he inserts a fictional character in a real situation, with the effect already noted. This mix is necessary for satirical treatment, as Herbert (1984: 407) tells us:

[T] he exhilaration of comic make-believe is dissipated if we are allowed to lose sight of reality altogether. Thus, comic writers never cease incorporating into the comic world subtle or quite overt recollections of the non-comic one, asking us always to measure precisely the varying angle of refraction set up between the play and what we think of as reality.

Whether one places a fictional character in a real situation or a real person in a fictional situation, the combination serves to highlight the oddness of the situation, and thus its openness to satirical treatment. It is especially important for Saki to give the reader this indication in his political writing, because for him the "angle of refraction" between truth and fiction is difficult to establish, given that politics is such a close mix of reality and fiction.

Valerian disappears after this first report, whereas Clode continues to appear in the pages of The Outlook. Before leaving Valerian behind, however, it is interesting to note two things about him. First, the comments on dress that describe Valerian in the first paragraph of the first dispatch are similar to those that Saki uses to describe his short-story characters, such as Reginald and Clovis [7]. Second, Valerian has had the opportunity to make a teasing remark to Clode; he is, thus, marked as a contributor to the humorous effect. He has another chance to participate in the humour nearer the end of the first report:

\footnotetext{
"Poor, dear Elibank abandoning politics two years ago," observed Valerian, "reminds one of the villain in melodrama who abandons the village maiden in Act I, and never gets a moment's peace from her during the rest of the play. Even in the tropic swamps of Bogota she turns up, tearful and insistent, triumphant over all difficulties of distance and transport." (21 Feb: 233)
}

A suggestion for this lively participation then disappearance can be offered through the study of Saki's fiction. The character mentioned above, Clovis, first appears as a fairly minor character in the short story Tobermory [8]. Later, he becomes a dominant character, receiving his own collection, The Chronicles of Clovis, in 1912. It can be concluded that, in the same way in which Saki experimented with this and other characters before fully developing them, he is briefly playing with Valerian and Clode before deciding on just what narrative strategy to take. This parallelism reinforces the idea that Saki is infusing his political reporting with writerly techniques; his chronicling practices are imitating those of his fiction.

However Saki's decision-making process functioned, it is Clode who receives the privilege of continuing in the chronicle. Each appearance presents acid commentary on the preceding session, beginning with the end of the first report. The reporter (ostensibly Saki, but more on that later on) compares Lloyd George (the Chancellor of the Exchequer) to Saint 
Sebastian, attacked from all sides at the end of the session, especially by a member named Pretyman. Clode corrects him.

\begin{abstract}
"It's not Saint Sebastian, you know," said Clode to me afterwards; "on these occasions he reminds me of the line: 'Oh, a pitiful man was Saint Aloys.' But he will have his revenge. He will discover that Pretyman's grandmother sold a piece of waste land to a needy community for some preposterous figure. Of course it will turn out that the figure was one-sixth, that it wasn't waste land, and that it wasn't Pretyman's grandmother. But Saint Aloys will have had his little moment of revenge; only a little moment, certainly, but then, you must remember, he is only a little man.” (21 Feb: 233)
\end{abstract}

Clode ridicules the Chancellor of the Exchequer by exaggerating his habitual political mudslinging tactics, involving personal insults made to opponents. He creates a particularly elaborate form of insult, and then ridicules it by showing that it would be false. After such preparation, Clode sums up, in an epigram, the different aspects of the imagined insult: the immediate effect and the character of the person who produced it, the short success of the attack, only lasting until the discovery of the lie, and the smallness of the man who created the attack. This comment illustrates at once Lloyd George's character and that of Clode, who is somewhat like Saki's fictional character Reginald, an inveterate troublemaker.

Clode is aware of the comparison with Saint Sebastian, and thus the contents of the article, which had been neither written nor printed when the conversation took place. He is aware of the notion without having read it. This privileged knowledge still only exists in the mind of the reporter at the moment during which Clode is speaking to him. This important fact further underlines the fictional quality of this Member of Parliament. A careful reader will immediately recognize the mixing of fiction and fact, and identify the author's clue in it [9].

The most important element in this comment is the humour on which it is based; this acerbic form of comment is in Saki's own style. The nature of the caricature on Lloyd George's personal attacks is typical of Saki, as is the direct, subtle comment on his smallness. The rhythm and the diction follow Saki's prose and, according to witnesses, his conversation. Clode is, thus, if not the embodiment of Saki, his spokesman. This interpretation is equally supported by the fact that Lloyd George is both Saki's and Clode's favourite target. In another example, we have Clode commenting on the Minister's extreme pride and tendency to boast.

"Rather annoying", said Clode, "for a man to boast that he's 'got the Tories on the run,' and then to find that he's left their candidate in a comfortable sitting position." (28 Feb: 272)

In a play on meanings which resembles that used by Saki's character Clovis, Clode transforms Lloyd George's exclamation into nonsense. This mockery also shows the conservative's disdain for a left-wing man, an attitude that Clode shares completely with Saki.

A similar attack appears in a later report:

Momentary lull settled on the House while members tried to apply themselves to the case of certain venturesome crofters. Met Clode in the lobby. "It is up to Lloyd George now to discover something discreditable in the annals of the Gough family," [Clode] said: "his admirers will certainly expect that of him. He can find out that one of them behaved in a craven fashion at the battle of Preston Pass; if it is subsequently pointed out that no member of the family was present at that battle he will crushingly retort, 'That shows how they have always skulked whenever there was fighting to be done!'” (28 Mar: 414)

Again, Clode describes Lloyd George's insult tactics [10]. Through Clode and in this revelation of Lloyd George's accusation, Saki gives us an illustration of political incongruity through satirical incongruity. Highet (1962: 11) highlights the absurdity and incongruity of 
the satirical universe in the expression that he borrows from Shakespeare: "a tale told by an idiot". [11] Clode's explanations introduce a tinge of idiocy into Lloyd George's speech, thus connecting it to the absurdity of the political situation. Through this commentary, Lloyd George comes to be seen as an idiot, and his speech as a collection of fabrications.

Once his idiotic nature is established, Lloyd George need only be mentioned for the designation to emerge in the mind of the reader. Saki tells us: "Clode says, "It would be such a convenience to have someone on the Treasury Bench again who understands the Insurance Act"' (14 Mar: 352). The Treasury is Lloyd George's function in the government, and the institution of state health insurance is his own invention. Saki implies, through Clode, that Lloyd George fails to understand even his basic function in the government and his own ideas. In another passage, the reporter relates Clode's comments about Lloyd George's attempts to modify the official record of his words in the Chamber (4 Apr: 452). The tone of ridicule in each of these quips is both evident and deducible through their juxtaposition with the absurdity of the earlier quotations. Previous ridicule infects these new comments. In this passage, the association of Lloyd George with his seat in the Commons and with his own proposal constitutes an indirect accusation of incoherence. Clode, thus, accumulates references to the minister and his shortcomings, each time with more and more subtlety.

This proceeds to the point where it becomes enough merely to juxtapose Clode and Lloyd George, to put them together in the same passage, to designate Lloyd George as an idiot. The association of the two names in the text becomes in itself a signal for irony, without the reasons for the irony being evoked:

I met Clode late that night at the Louis d'Or and we drank to the Fates, whom I had justly suspected of undue favouritism; I am not certain that we ought not also to have gratefully toasted Lloyd George. (16 May: 678)

Lloyd George is mentioned here because he engaged in a failed attempt to rally the town to his cause. Thus, the Conservatives won their point, and Clode and the reporter celebrate. There is no specific criticism of Lloyd George in this passage. Clode's appearance is the mark of the satirical treatment of Lloyd George. It is not necessary for Clode to engage in his typical irony, which resembles Saki's so much; the use of his name in the passage carries in itself the irony of the passage, and his diegetic presence authorizes the reader to suppose that the comment is an attack.

This highlights another tendency in Saki's reports: Clode is often the one to have the last word. This fact also supports the idea that Clode is a fiction: in Saki's texts, no politician ever has the last word. In addition, this position at the end of the chronicle allows Saki to finish his report in an ironic tone, so that the reader retains, of all the report, this last thrust of satire. This is necessary, given that Saki is presenting real chronicles of the sessions, giving the reader the main points of the actual discussions, debates, and decisions of the week. These facts are mixed with the acerbic comments attributed to Clode, which are definitely the work of Saki, but which are not allowed to dominate the body of the report. The events must be related somewhat truthfully, as it is a political chronicle. Because of this, the relater of the events must avoid presenting himself as an unreliable reporter; thus, Saki offers what one would call the 'irresponsible' comments to Clode. The last comment in the report always confirms the satiric slant that Saki wishes to apply to politics, without colouring the entire report, and that satiric slant is attributed to and established by Clode, leaving the reporter stainless.

The link between Clode and the satirical tone of the chronicle is proven in other ways as well. First, Saki opposes Clode by actually giving compliments to Lloyd George: 
With crowded benches of supporters behind him, ready to cheer his wildest assertion, and to giggle at his most trumpery flippancies, Lloyd George was quite capable of putting up a good fight. (21 Feb: 233)

Saki's praise can be seen as begrudging, but, nonetheless, it is given. In the same way he refers later to "the brilliant Mr Winston Churchill" (25 Apr: 552). He also praises the departed Mr Seely: "Whatever Seely's deficiencies may have been, at least he possessed a quietly effective manner in dealing with questions" (25 Apr: 551). Clode gives no compliments of any type in any of his commentaries.

Secondly, the reporter engages in humorous play at different times in the column, but it is almost always present as metaphors involving animals or, occasionally, inanimate objects:

Sir David Brynmôr Jones, with his voice of honey, suggestive of a July afternoon in an apiary, [...] (21 Feb: 233)

Ward is a human samovar, bubbling over with self-esteem. (28 Mar: 415)

[Redmond] was in the position of a captive golf-ball, that can describe beautiful flights and curves in the air, but can go no farther than its line allows it. (11 Apr: 486)

[Asquith] waddles away from questions with the triumphant air of a duck waddling from under the wheels of a motor-car. (25 Apr: 551)

There was Robert Harcourt near to hand, clicking and fluttering with the emotion of a hen whose pet chicken has been nearly pounced on by a cruel hawk. (25 Apr: 552)

[An Independent Nationalist MP was] a cat that cannot make up its mind whether it wants to play with a mouse or eat it, and as a result if its indecision the mouse was able to slip away. (27 Jun: 871)

Crewe was dignified, correct, and dispassionate, suggesting to one's mind an archangel who regarded the Creation of the World as a risky and unnecessary experiment but had no intention of saying so. (18 Jul: 71)

These metaphors are playful but not biting, as Clode's comments are. They add colour to the report, a goal that Saki has shown from the beginning, but without adding any acidity.

Finally, Clode's satirical function is demonstrated by reversed parallelism. Except for two brief appearances (and the "Louis d'Or" passage is one of them), Clode disappears from the chronicle from the $25^{\text {th }}$ of April. Then the tone of the chronicle becomes more exasperated and bitter. At that point Saki has stopped playing with the subjects that he is treating and becomes more serious in his criticism. For example, his assessment of Lloyd George is blunter:

The spectacle of the Chancellor of the Exchequer approving of all his works is almost as familiar as the companion picture of the Chancellor of the Exchequer finding words to express his loathing of the private lives and family histories of his opponents. (16 May: 677)

His last report, on the $8^{\text {th }}$ of August 1914 announces the declaration of the war, and it is written in the most sober tone that he had ever used.

From these observations, I can define Clode's function and the logic of creating a fictional being in a real situation in this way: making use of an auxiliary, the author can deliberately create a satire in a newspaper article that covers real current events [12].

The tendency to attribute the humorous commentary to Clode can also be linked to Saki's tendency to avoid putting himself forward, to let his prank have its effect without him necessarily being there. Like his fictional characters, he stands aside to let the humour take 
the fore. In the previously quoted comments or others - such as remarks about Lord Roberts (18 Apr: 518) or a proposed nickname for Asquith (4 Jul: 7) - Clode produces his sharpest epigrams, while Saki contents himself with being the chronicler. Like Reginald, Saki is 'absent' when the verbal attack is perpetrated. He can only be held responsible for reporting it, not for producing it.

As I had indicated at the beginning of this study, there are different tones that Clode and Saki use to convey their satire. For example, Clode closes one report in the style of a parable.

"Did you ever hear [...] of the elephant that came across a motherless brood of partridges in the jungle, and, saying 'I will be a mother to them,' sat down on them?" (7 Mar: 303)

This comment is made in response to a Member of Parliament who has offered to take a proposal under his wing. Clode also often ends in an epigram, an understatement subtly summarizing the situation and Clode's attitude toward it, like these:

"You may bring a Labour member to the verge of hysterics, but you cannot make him vote," observed Clode. (21 Mar: 383)

Talking of dictation, Clode assures me that the Government's next attempt at solving the Irish Question will be to make Birrell Dictator for life, with perpetual leave of absence. (25 Jul: 103)

However chary Ministers may be about giving information, there is one thing they are ever ready to do, and that is to talk. (21 Mar: 383)

Clode can even engage in poetic parody:

As Clode has aptly improved on Omar:

The moving finger writes, and having writ

Not all their irony or all their wit

Can pin you down to anything you said. (11 Apr: 486)

Saki will also vary the structure by sometimes giving Clode a clearer explanation of their attitude. In this comment Clode uses a metaphor to comment on the government's treatment of Home Rule:

"Do you remember the celebrated Madame Humbert," Clode asked me in the lobby, "the woman who hoaxed and mystified all Paris a few years ago with an empty safe which was supposed to be packed full of securities? Asquith has become the Madame Humbert of British politics. He has a wonderful safe full of concessions and safeguards and guarantees, but when the House shows a pardonable curiosity as to the actual contents of the safe he finds it inconvenient to produce the key." (21 Mar: 383)

Clode explains clearly the metaphor and its meaning - Asquith pretends to have a solution to the problem, but never presents it when pressed to. Clode, thus, adds irony to direct criticism.

These passages demonstrate that one of the elements of literature, the capacity to vary the tone of a narrative, is inserted in the text of a chronicle. The mix of fact and fiction which has been accomplished using characters continues with the mix of the writing styles for fiction and for reporting.

It has been noted that Clode uses a metaphor in this passage. However, as has been indicated, it is erroneous to link these comments directly to Clode; his style is that of Saki. For this reason, the movement from narration by Saki to narration by Clode can sometimes occur without a change in tone.

Snowden [...] harangued the House at inordinate length, but with a frolicsome air of irresponsibility, on the iniquity of armament firms and the frailty of politicians. Snowden is that rare and precious thing, a 
socialist with a sense of humour; there is another somewhere, but I have forgotten his name [...] One or two strangers in the gallery, evidently immune from a sense of humour, broke out into fervent applause. Obvious, as Clode remarked, that if wit had not already existed in the world, Snowden would long ago have invented something like it. (21 Mar: 383)

In this passage the commentary comes mainly from Saki, who introduces the irony into the description and designates himself in the expression "I have forgotten" [13]. The comment added by Clode does not change the tone of the passage. Saki, thus, allows the varied styles and tones to combine, yet again winking to the reader to confirm the fictional status of Clode.

\section{Effects of the Device}

The question of the character of Clode leads to that of Saki's authorial intrusions in the text. It has been indicated that Saki, the faithful reporter of Parliamentary facts, is hiding behind Clode, the impish satirical commentator. However, this mix of styles and tones just examined shows that Saki is in fact only half-hiding. This gesture parallels that used in his fiction. Lambert (1956: 211) is among many critics who feel that Saki is closely reflected in Reginald, Clovis, and his novelistic hero Comus Bassington. In the same way, Clode is the double of Saki. Lambert (1956: 212) refers to Saki as "a jungle-boy in the drawing-room"; by this he means that he participated in English middle-class society all while pillorying it in his short stories. In the same way, Pritchett (1957: 19) refers to him as "a performing lynx". These metaphors of savage, primitive beings are revealing. In his satire, Saki was savage like the wild animal or wild boy depicted by these critics; and as a jungle boy or lynx, he was operating in contradiction to the sedate society around him. But he was performing in the 'drawing room' of the society he was criticizing; he was an established member of an established class, even though he criticized it. He participated in English society's usual activities and appeared at the dinner parties and country weekends that gave him his material. Gore (1940: 316) observes that "He enjoyed its many amenities and luxuries, while he lashed at its follies, its blindness and its vulgarities". This position - half-out, half-in - like the Oscar Wilde window in the Poets' Corner in Westminster Abbey, is mirrored in Saki's characters, including not only Clode, but also the reporter of Potted Parliament, himself half a fiction. We, thus, have yet another sign that Saki's reporting is imitating his fiction writing.

In this way, Saki shares his intrusions between the created character and direct reporting. The violation of both worlds, fictional and real, finds its parallel in the violation of the narration by ironic comments. Saki subtly creates the equivalent of his fictional havocwreakers' pranks in which certain rules are bent, creating a new situation. The victims of the fictional pranks are scandalized, but through Saki's subtle juggling between himself and his created Member of Parliament, his reporting style avoids outraging the readership. However, his vivacity signals an innovation in reporting which comes from his literary activities. Saki presents himself here as a joyous prankster, a player in the game, taking advantage of the rules of reporting to create moments of play freed from these rules. The liberating effect of this approach acts equally on Saki, the reporter, and on the Parliamentary report.

This question of liberation leads to that of the allowance of liberation. The concern is whether Saki was at cross purposes with his employers at The Outlook. To what extent Saki was free to introduce characters and mix tones and styles cannot be chronicled precisely, but the continued presence of these techniques suggests that one can draw the conclusion that The Outlook accepted and perhaps even welcomed this original approach.

The reasons for Saki's choice can also only be deduced, but some of them are fairly easy to discern. Saki's writing style was consistent from his very first publication - his short 
story Dogged in St. Paul's in 1899 - to his last - the essay On Being Company Orderly Corporal in the Bystander. His political writings had shown no tendency to differ from his fiction writings in earlier works, and no evident reason for making them differ appreciably can be concluded in the case of The Outlook.

One could also propose that Saki used a lighter tone and a fictional character in order to protect himself and hide behind a humorous personage for his attacks on the government in power, which had a very active system for censorship. For that institution, he may have needed to moderate his comments [14]. On the other hand, it was not necessary to moderate his tone for The Outlook; as I have indicated, this periodical was an openly conservative publication. Saki is, therefore, free, in the context of the periodical, to fustigate the Liberal Party.

Therefore the light, humorous tone that he gives to his column is most likely present to allow Saki to turn the tone of the column from one of political commentary to one of satire of the government. Saki uses his 'harlequin costume' - his light, epigrammatic language - to valiantly expose the government's failings. The Outlook reports also show that there can be an advantage to introducing a fictional character into a column of correspondence; the character presents the situation with more colour, and gives Saki more freedom to express the situation in a more immediate, human fashion.

\section{Conclusions}

In Potted Parliament, Saki shows a political acumen which contributes to the skilful construction of the Outlook articles. He had also learned to pull his punches and to give the right dose of humour in his reports. Saki, nonetheless, writes for The Outlook in his signature style, established from the beginning of his career, and it served to enliven the reading and hone the judgment of the reader.

The Outlook correspondence was the last lengthy occasion for Saki to hone that judgment. Saki enlisted as soon as possible in the war. While a soldier, he wrote a few pieces for different periodicals, but none of them contained political satire. The full circle of his political commentary had already been closed. Potted Parliament is a final echo of The Westminster Alice, and nothing following that correspondence would have showed the same level of either humour or political observation.

In all of Saki's works, humour gets the upper hand over all that is strident or timid in life and in politics. Lilly (1978: 6) says in his work Four English Humorists of the Nineteenth Century: "The humourist [...] is an artist who playfully gives us his intuition of the world and human life". This description can also serve for a certain type of journalist in a trade in which one is also sometimes called upon to give an intuition of a situation. Saki found a way to unite political intuition and humoristic style in his dispatches and create a seamless unity from two writerly worlds. In addition, the seamless insertion of fictional material and characters allowed for ripe comment, continuity, and variety of tone in his works. When one sees the whole of Saki's writing, one sees more clearly the "keen analysis, sound common sense, and felicity of statement" of Saki (Saki 1900b: 201) [15]. And whatever form of humour is used is always presented with artistry and lightness of touch. The careful balance of political commentary, humour, and fiction fully accomplishes both Saki's purpose and that of the Outlook. These and other political commentaries by Saki are worth closer study in any context of political humour or even political science because of their accuracy and their bite. 


\section{Notes}

[1] There are only a few exceptions to this process: for example, the short stories The Music on the Hill, The Story of St. Vespaluus, The Way to the Dairy, The Secret Sin of Septimus Brope, and The Remoulding of Groby Lington, and a longer and modified version of Ministers of Grace appear for the first time in the collection The Chronicles of Clovis (Saki 1912b).

[2] See Koss (1984: 3, 4). There was still the necessity to avoid some measure of censure. For a discussion of this problem, see Birden (1996: 313-317).

[3] See also Nevinson (1926: vii).

[4] For details of the incident, see Ensor (1992 [1936]: 477-479).

[5] AA 2005 Large Scale Britain (Windsor: AA Publishing, 2004). There is however a Weston Subedge in Gloucestershire (AA 2005 42), sometimes misspelled as Western Subbage in official documents (see, for example, The Traffic Commissioner for the West Midland Traffic Area Notices and Proceedings 8 Oct 2004: 10).

[6] Langguth (1981: 105) identifies similar fictionalized passages in Munro's Balkan dispatches.

[7] See, for example, Reginald (Saki 1904: 5, 9), and The Match-Maker in The Chronicles of Clovis (Saki 1912b: 25).

[8] First published in The Westminster Gazette XXXIV (5,167), pp. 2-3 (Sat 27 Nov 1909).

[9] It is possible to refute this argument by suggesting that the reporter could have mentioned this comparison to Clode during a non-reported part of the dialogue. I would suggest that the text is creating the diegetic environment and that whatever does not appear textually cannot be considered part of the diegetic environment.

[10] Such descriptions also appear in Saki's fiction, especially Ministers of Grace (Saki 1912b) and More About Him (Saki 1912a).

[11] The quotation is from Macbeth V.v.16-27 (Shakespeare 1993).

[12] It is possible to interpret Clode in the sense of a Proppian helper, either in his function of filling a lack or that of accomplishing a difficult task; see Propp (1970: 96).

[13] The name that Saki 'has forgotten' is that of George Bernard Shaw, and Saki 'forgets' his name deliberately in order to slight Shaw, who is another of his favourite butts.

[14] On the necessity of protection, see Schutz (1995: 52-54).

\section{References}

Birden, L. M. (1996). “One's bitterest friends": Dynamique de Caractère et Humour chez Saki. Nice: University of Nice PhD thesis.

Chesterton, G. K. (1926). 'Introduction', in Saki, The Toys of Peace: The Collected Works of Saki, London: John Lane The Bodley Head, pp. xi-xiv.

Dod's Parliamentary Companion for 1914. London: Whittaker.

Ensor, R. C. K. (1992 [1936]). England 1870-1914. Oxford: Oxford University Press.

Gore, J. (1940). 'Saki', in Russell, L. (ed.), English Wits, London: Hutchinson, pp. 307-326.

Herbert, C. (1984). 'Comedy: The World of Pleasure'. Genre 17 (4), pp. 401-416.

Highet, G. (1962). The Anatomy of Satire. Princeton: Princeton University Press.

Koss, S. (1984). The Rise and Fall of the Political Press in Britain. London: Hamish Hamilton.

Lambert, J. W. (1956). 'Jungle Boy in the Drawing Room: J. W. Lambert on Saki'. Listener 15 (146), pp. 211-212.

Langguth, A. J. (1981). Saki: A Life of Hector Hugh Munro. New York: Simon and Schuster. Lilly, W. S. (1978). Four English Humorists of the Nineteenth Century. New York: Norwood.

Nevinson, H. M. (1926). 'Introduction', in Saki, Beasts and Super-Beasts: The Collected Works of Saki. London: John Lane The Bodley Head, pp. vii-xii. 
Pritchett, V. S. (1957). 'The Performing Lynx'. New Statesman 53 (1347), pp. 18-19.

Propp, V. (1970). Morphologie du Conte. Trans. Derrida, M., Todorov, T. \& Kahn, C. Paris: Seuil.

Saki. (1899). 'Dogged'. St. Paul's: An Illustrated Journal of the Day 250 (19), pp. 205-206.

Saki. (1900a). The Rise of the Russian Empire. London: Grant Richards.

Saki. (1900b). 'The Rise of the Russian Empire'. Review of The Rise of the Russian Empire by Saki. Nation 72 (1862), p. 201.

Saki. (1902a). 'Not so stories (with apologies to R. K.)'. Westminster Gazette XX $(2,975)$ XX $(2,998)$.

Saki. (1902b). 'The political jungle-book'. Westminster Gazette XIX $(2,774)-X I X(2,858)$.

Saki. (1902c). The Westminster Alice. London: Westminster Gazette.

Saki. (1903). 'The angel and his lost Michael.' Morning Post 16 Nov, p. 5.

Saki. (1904). Reginald. London: Methuen.

Saki. (1912a). 'More about him: The fifth volume of the life of Mr. Lloyd George'. Bystander XXXVI (461), p. 18.

Saki. (1912b). The Chronicles of Clovis. London: John Lane The Bodley Head.

Saki. (1914). 'Potted parliament'. The Outlook 33 (838)-34 (862).

Saki. (1915). 'On being company orderly corporal'. Bystander XLVI (603), p. 468.

Saki. (1919). The Toys of Peace. London: John Lane The Bodley Head.

Saki. (1926). The Collected Works of Saki. London: John Lane The Bodley Head.

Schutz, C. E. (1995). 'Cryptic Humor: The Subversive Message of Political Jokes'. Humor: International Journal of Humor Research 8 (1), pp. 51-64.

Seamon, R. (1987). 'Acts of Narration'. Journal of Aesthetics and Art Criticism 45 (4), pp. 369-379.

Shakespeare, W. (1993). Macbeth. Oxford: Oxford University Press. 